\title{
Implementation of manipulative speech tactics in translation (based on English and Spanish journalistic texts)
}

\section{Реализация манипулятивной речевой тактики в переводе (на материале английских и испанских публицистических текстов)}

\author{
Received: February 27, $2021 \quad$ Accepted: March 30, 2021
}

\author{
Written by: \\ Vitaly V. Kabakov ${ }^{5}$ \\ https://orcid.org/0000-0002-8648-6317 \\ https://www.scopus.com/authid/detail.uri?authorId=8430822500 \\ elibrary.ru: https://elibrary.ru/author_profile.asp?id=1023894 \\ Paola Julie Aguilar-Cruz ${ }^{6}$ \\ https://orcid.org/0000-0001-8386-9104
}

\begin{abstract}
The article is devoted to the analysis of the use of manipulative speech tactics, which are actively used in journalistic texts to form a certain impact on the target audience. The article explores the tactics on the example of English and Spanish speech techniques. The purpose is to study the influence of manipulative tactics on journalistic discourse. The research methodology includes an analysis of newspaper and journalistic texts popular in the United Kingdom and Spain. The article explores the strategies of manipulative speech techniques in political discourse. In journalistic texts, speech techniques have a peculiarity in manifestation in the multilevel perception by the reader. For political discourse, a special role is to use metaphors. Tactics based on speech techniques, including visual and expressive means (metaphorical models), are in every language culture. Manipulation here will be considered as a means used for the implicit implementation at the mental level of specific goals, intentions, and attitudes that do not coincide with those that the target audience currently has. Communication in political discourse has the only goal: to influence the object of influence. Therefore, the basis for using manipulative speech techniques is to use a strategy of influence and control by public consciousness.
\end{abstract}

\begin{abstract}
Аннотация
Статья посвящена анализу использования манипулятивных речевых тактик, которые активно применяются в публицистических текстах для формирования определенного воздействия на целевую аудиторию. В статье исследованы тактики на примере английских и испанских речевых техник. Цель заключается в исследовании влияния манипулятивных тактик на публицистический дискурс. Методология исследования включает анализ газетнопублицистических текстов, которые пользуются популярностью в Великобритании и Испании. В статье исследуется стратегии использования манипулятивных речевых техник в политическом дискурсе. В публицистических текстах речевые приемы имеют особенность в проявлении на многоуровневом восприятии читателем. Для политического дискурса особая роль заключается в использовании метафор. Тактики, основанные на речевых приемах, включая изобразительно-выразительные средства (метафорические модели), есть в каждой языковой культуре. Манипуляция здесь будет рассматриваться как средство, используемое для неявного внедрения на ментальном уровне определенных целей, намерений, установок, которые не совпадают с теми, которые имеются у целевой аудитории в данный момент. Коммуникация в политическом дискурсе преследует единственную цель - оказать влияние на объект воздействия. Следовательно, основа
\end{abstract}

\footnotetext{
${ }^{5}$ Senior Lecturer, Moscow Aviation Institute (National Research University), Moscow, Russia.

${ }^{6}$ Master degree in Education from Universidad de Medellin. English teacher at Jorge Eliécer Gaitán High School and Amazonia University. PhD student in Educational Technology at Central China Normal University, Colombia.
} 
Keywords: manipulation, influence, journalism, public, politics.

\section{Introduction}

Language is the main tool for manipulating public consciousness. Journalistic texts can create and shape ideological trends, a system of beliefs and values only for controlling human consciousness. The journalistic environment characterizes writing as a unified means of communication.

A publicist text is a communicative unit, firstly, informing about the object of the message, forming and maintaining interest in it and responsible for its promotion in the political arena, that is, one of the texts of marketing communications (distinctive feature); secondly, as information recognized by the consumer precisely as an advertising text, and thirdly, a text having a polysemiotic communicative nature (specific communicative feature). The most important feature is the manipulative component.

The study of the concepts of feelings and emotions and how they are realized in the linguistic space is one of the most interesting objects of study in linguistics. The study of this phenomenon is engaged in such linguistics, called political linguistics. Political linguistics is a relatively young science, it is an interdisciplinary science - linguistics and political science - and is concerned with the study of the influence of socio-political events on changes in language and vice versa. The subject of this science is political communication, or in other words, the speech activity of a politician, which is aimed at emotional impact, propaganda and the creation of political sentiments in order to strengthen their positions or, on the contrary, to worsen the authority of their rivals.

There are several options for understanding a political text. Some delimit the definition of a political text. Some refer to it as a text that is widely used in the field of politics and government. Others believe that a political text can be called any text that is somehow related to the political sphere. Nevertheless, both sides agree that the main distinguishing feature of political texts is that the potential recipient is a mass audience. The main function of such a text is to influence the listeners so as to obtain the использования манипулятивных речевых техник заключается в использовании стратегии влияния и контроля общественным сознанием.

Ключевые слова: манипуляция, воздействие, публицистика, общественность, политика.

desired effect, depending on the speaker's intention.

Despite the fact that initially political texts belonged to the official business style due to its use in business and management, today political texts are the center of analysis for many linguists, since public speaking has become a frequent phenomenon in the political arena. Public speeches are aimed, as mentioned above, at communication and communication with the people, getting support from potential voters, and so on. Monotonous and emotionless speech, which was made on the basis of a text related to the official business style, is quite difficult for a person to perceive, especially for an audience of thousands. Therefore, the view of the conduct of politicians' speeches has changed and emotionality has begun to be tolerated in writing political texts.

\section{Theoretical Framework}

Manipulative techniques in speech activity were investigated by the following methods: analytical and sequential-textual on the example of studying newspaper headlines and the content of journalistic texts (Shaw, 2014).

A newspaper and journalistic discourse that can create an information space is somehow based on ideological background (the publisher's worldview regarding certain political events) or is dependent on personal characteristics (the subjective attitude of a journalist) (Chernyavskaya, 2006; Klushina, 2008).

Manipulative speech tactics thus have a psychological effect on the recipient in order to consolidate influential positions. The speech effect depends on the language itself and its special speech-producing functions. Researchers of manipulative tactics associated with speech means (Altunyan, 2017; Burova et al., 2020), have identified a typology of manipulative influence regarding speech means:

- $\quad$ imagery as a method of distraction;

- $\quad$ highlighting the sign system;

- designation of "roles"; 


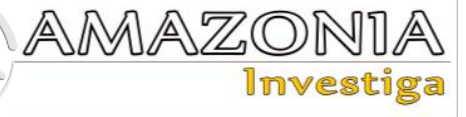

- identity of the addressee as a method of exploitation;

- moral and spiritual values as a factor of conversion.

The effective implementation of manipulative speech tactics includes a variety of techniques and techniques. For example, a frequent trick is "emphasis shifting", which allows the recipient to be distracted, and with the help of this, the reader will then pay attention to additional facts that may be irrelevant; changing target tactics so that the recipient does not doubt the "correctness" of decisions.

Newspaper and journalistic texts often resort to "shocking" the facts of readers; creating the image of an explicit "protector" with good intentions or a "villain" who is trying to accomplish the unthinkable. The shocking tactics was initially aimed at creating a biased attitude among the target audience. The emphasized emphasis on the advantages of the "defender" and the shortcomings of the "villain" creates in the aggregate the "necessary" image of the target audience, which was originally already registered. Readers may agree with an extraneous opinion, so this tactic is called "social responsibility".

\section{Methodology}

For English-language texts, the fact that the influence function prevails over the message function is noteworthy. The transmitted informational message is transmitted using value judgments, often veiled (Ukhov et al., 2020). The acting function of many journalistic texts is regulatory. An analysis of the English-language headings in journalistic text shows that the most common tool is a rhetorical question addressed to the reader. "Who Rules the Internet?", for example (Röckel, 2017).

To convey the expressiveness of the expression of thoughts, a technique is used due to short, emotionally-colored sentences: such as "The army is nervous" or "The police want that army to do it". These manipulative tactics are used to focus the audience (Chavez, 1984).

The English headings of journalistic texts try to draw the reader's attention to the problem under consideration. The headline highlights the most striking thought, which will be discussed in the text itself (Lukanina, 2003; Eremina \& Krapivina, 2019).
On the contrary, journalistic texts use ideological propaganda as the most proven technique in political discourse. For example, when the new British Prime Minister Boris Johnson came to power, they wrote about him in articles as a suitable replacement for Theresa May “...but his charisma, flair for publicity and record of winning...make him the runaway favorite in a crowded field to succeed Prime Minister Theresa May...". Epithet "runaway favorite" emphasizes favor and confidence in the new Prime Minister (Castle, 2019).

Political events in the United Kingdom related to Brexit's most painful topic are the subject of journalistic exploitation. For example, in a newspaper "The Telegraph" shows that "...this country has been trapped by Brexit - like supergreen supercar blocked in the traffic". The sentence presents a language construct «trapped by Brexit» with a pronounced negative color; comparative turnover «like super-green supercar blocked in the traffic», so that readers have formed a certain association in connection with the difficult situation of the country (Boris, 2019).

The newspaper also provides a metaphor "Like Tantalus in Hades", that is, a direct reference to ancient Greek mythology about Tantalum, which was imprisoned by Hades, doomed to eternal torment. Such a "shocking" speech technique will create a panic mood among the target audience (Boris, 2019).

Therefore, in spite of the fact that journalistically texts are traditionally referred to texts transmitting this or that important information, now their strength lies in exerting ideological influence on readers (Boyd, 2018).

In Spanish-language journalism there is a similar maneuver of exaggerating the current state of affairs in the country. "Como rescatar al pais que afronta el abismo de unaprofunda crisis?" The translation is: "How to save a country standing at the abyss of a deep crisis?" Speech reception, as a rule, refers to the perception of a person, using the image of the "terrible situation" in the country to shock the audience (Razeto, 2008).

Spanish journalistic texts are distinguished by special emotionality, expression, expressed in the use of metaphors, epithets, comparisons, hyperbolas to create a stable image among readers. 
The political ideology is a frequently encountered manipulative device in journalistic texts. The ideological function lies in the formation of people's perception and concentration on certain controversial events, which are given a direct stable assessment (Cialdini, 2000).

Spanish journalistic texts often reflect political events through a variety of manipulative speech tactics. An important problem of Spain is separatism in relation to Catalonia. The resignation of the head of the Catalan government, Carles Puchdemon, led to numerous publications, where the newspapers thereby attempted to form their opinion about Puchdemon (Sánchez, 2018).

The article "Los 100 dias de Puigdemont en Bruselas" described Puigdemon as an idle man who is not interested in his own country. Authors of the article use ideology «profugo», meaning «fugitive». Journalists use this manipulative technique to create an image for the target audience in the context "profugo de la ley". The phrase is considered as "lawless fugitive" (El Mundo, 2018).

Another title uses a strong phrase «la dolche vita» in relation to Puchdemon. «La dolce vita del fugado Puigdemont en Bélgica» in a weekly newspaper article «El Mundo». In this context, the manipulative technique aims to consolidate the image of the audience, once again emphasizing that Puigdemon fled to Belgium, and there he is satisfied with a good life (Sánchez, 2018).

\section{Results and Discussion}

The analysis of the theoretical material on the issues of the journalistic text allowed us to define the basic concepts of the research.

The main pragmatic goal-setting of a political text to influence the recipient is actualized in the word and implemented through the text created by the communicator, that is, the addressee. The addressee makes a logical emphasis or highlights an element of the information chain by manipulating a number of linguistic units and structures.

A political text is a text of a special kind, the main specificity of which lies in its pronounced pragmatic character, which cannot but influence the strategy of construction, the choice of linguistic means.
Political messages differ from ordinary informational messages in that they perform the function of an admonishing influence on a person in order to induce him to join one or another ideology.

The process of human behavior in the political sphere is influenced by both external and internal factors. External factors are everything that is happening around you at a given time: people nearby, weather conditions, etc. Internal factors are everything that happens inside you at the same moment in time: your attitude to various things, health status, views, beliefs, past experiences. A political message should have such "functional properties as informativeness, persuasiveness and suggestiveness to inspire confidence and create an emotional connection between the addressee and the recipient

Researchers also distinguish between strategies by the means of influence used: predominantly verbal-oriented, predominantly non-verbaloriented and mixed; phonetically or semantically oriented verbal strategies and their mixed versions; strategies based on the use of predominantly explicit or implicit communication means, etc.

The use of the category of emotiveness often intersects with speech manipulative techniques. It is with the help of manipulations and certain language constructions that you can tune the audience to the mood that the speaker needs. Sheigal distinguishes between types of manipulation in political discourse, depending on the nature of information transformations (Sheigal, 2000). They are divided into two groups.

Referential manipulation is factual (lies, falsification of facts, exaggeration, understatement) and focusing (shift of pragmatic focus), which is associated with distortion of the denotation or referent image in the process of denoting reality.

Reasoned manipulation is associated with a violation of the postulates of communication: this is a violation of the logic of text deployment or the integrity of the text (avoiding the answer, switching the topic), evading the obligation to prove, masking logical moves (false arguments, objection under the guise of consent, etc.) (Sheigal, 2000).

It is also not uncommon to mention the use of such techniques as demagoguery by politicians in their speeches. Demagogy can be called false 


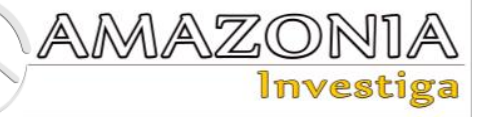

promises, deliberate distortion of facts and idle talk. Most often, these concepts of manipulation and demagoguery are separate from each other, but today demagoguery is considered as part of manipulation. In the use of manipulations, the mechanisms of suggestion are used, that is, one of the methods of influence of some persons on others, which is made intentionally or unintentionally by the influencing person and which can occur either unnoticed by the suggested person, or even with his knowledge and consent. One of these techniques is neurolinguistic programming (NLP). One of the main techniques of NLP is changing submodalities.

Submodalities are such elements with the help of which we form our idea of the surrounding reality, about specific situations and what emotions we experience. By changing certain submodalities, one can influence not only the strength of experiences, but also change the experienced emotions to diametrically opposite ones.

This technique works as follows: a person talks about a situation to which it is necessary to change his attitude (most often, this is a situation where he experiences negative emotions) and recalls a situation where he, on the contrary, experiences positive emotions. After that, the next step is taken - finding the differences between the first situation (to which you want to change the attitude) from the second. Next, replace the so-called submodalities (relation) of one situation with another.

The use of such a technique is often used by politicians when they are asked uncomfortable questions, and they want to change a person's attitude to these questions, to win them over, in other words, "tune in to their own wavelength".

When considering the theoretical foundations of the study of a journalistic text in the context of political messages, we can draw the following conclusions: different aspects of the study of journalistic texts have led to the difference in a large number of definitions of this phenomenon. It should be emphasized that a journalistic text is presented both as a text that carries certain information, and as a special type of genre, as a type of mass communication, as well as a communicative unit, a pragmatic focus, which is the transmission of information about the subject and influence on consumers.

To the foregoing, manipulative speech tactics are an attribute of newspaper and journalistic discourse. Studying English and Spanish texts, I identified specific manipulative techniques that were inherent - the use of value judgments due to the abundance of expressive-visual means (comparative turns, epithets, etc.) (Coxall, 2013). "Shocking" headlines attract readers' attention best. In this case, the text may not match the title, but the target audience will already be interested. Political propaganda tools - prejudice and the imposition of "opinions" always work together (Owen, 2017).

\section{Conclusions}

The effectiveness of political discourse is largely due to the choice of strategies for communicative influence, which is understood as the impact on the knowledge, attitudes and intentions of the addressee in the direction necessary for the addressee. The following distinctive features of political texts are distinguished: the special role of extralinguistic factors in shaping the choice of linguistic means, specificity of denotation, special pragmatic orientation, specificity of cognitive conditions and semiotic character of political text.

Based on the above, one cannot deny the fact that in political texts, which, although they refer to the official business style, there is the use of emotionally manipulative techniques. Thus, one can say that political texts are a separate genre of language. Further study of this phenomenon will provide in-depth study of the mechanisms of language manipulation and will help in the future to make negotiation or public speaking more successful and effective.

All in all, language in political discourse addresses feelings, desires, is focused on influencing the addressee, focuses on the meaning, on linguistic means, context, and simultaneously on all the listed characteristics. The structure of a political text depends on the prevailing function, however, more often than not, several linguistic functions are included in the advertising message.

The analysis of publicist texts showed that the set of linguistic means used in advertising is very diverse. The image created with the help of pictorial and expressive means acquires a brighter, more dynamic form, is easier to perceive and is quickly remembered by the reader. Additional information is added to the objective information, which is formed mainly due to stylistically colored vocabulary and syntax, phonostylistics to create a specific sensory image of the advertised object, emotionally evaluate the facts in question. 
Consequently, manipulative techniques may include speech strategies, techniques, and various manipulations. Speech techniques often found in journalistic discourse appeal to readers' perceptions (Stanley, 2016). The target audience is used to test manipulative tactics in order to use them to develop patterns of behavior among citizens, a deliberate reaction to an event. Thus, a person, as an object of manipulation, becomes controlled.

\section{References}

Altunyan, A. G. (2017). Analysis of political texts. Moscow: University book; Logos. Available at: https://elibrary.ru/item.asp?id=30660357 Boris, J. (2019). A deal is oven-ready. Let's get Brexit done and take this country forward. Telegraph. Available at: https://www.telegraph.co.uk/politics/2019/11/05 /deal-oven-ready-get-brexit-done-take-countryforward

Boyd, D. (2018). Media manipulation, strategic amplification, and responsible journalism. Points.datasociety. Available at: https://points.datasociety.net/media-

manipulation-strategic-amplification-andresponsible-journalism-95f4d611f462

Burova, A. Y., Ryapukhin, A. V., \& Muntyan, A. R. (2020). Reduced hardware costs with software and hardware implementation of digital methods multistage discrete Fourier transform on programmable logic devices. Amazonia Investiga, 9(27), 227-233. https://amazoniainvestiga.info/index.php/amazo nia/article/view/1231

Castle, S. (2019). In contest to succeed Theresa may, stars are aligning for Boris Johnson. New York Times. Available at: https://www.nytimes.com/2019/05/25/world/eur ope/boris-johnson-theresa-may.html

Chavez, L. (1984). The strongest contender, some say, is not in Salvador race. New York Times. Available at: https://www.nytimes.com/1984/03/24/world/the -strongest-contender-some-say-is-not-insalvador-race.html

Chernyavskaya, V. E. (2006) The discourse of power and the power of discourse: Problems of speech exposure. Moscow: Flint, Scientific press.

Cialdini, R. B. (2000). Influence: Science and Practice, 4th Edition. New Jersey: Allyn \& Bacon.
Coxall, M. (2013). Human Manipulation. A Handbook. Andalusia: Cornelio Books.

El Mundo (2018). La dolce vita del fugado Puigdemont en Bélgica. Available at: https://www.elmundo.es/f5/comparte/2018/02/0 7/5a7aba6de2704ebe1f8b4576.html

Eremina, N. V., \& Krapivina, M. Yu. (2019). Stylistic features of translation of English newspaper and journalistic texts. Bulletin of Tomsk State Pedagogical University, 5(202), 71-78.

Klushina, N. I. (2008). Communicative style of journalistic text. World of the Russian word, 4, 67-70. Available at: https://cyberleninka.ru/article/n/kommunikativn aya-stilistika-publitsisticheskogo-teksta Lukanina, M. B. (2003). Newspaper text through the prism of communication theory. Bulletin of Moscow State University, Linguistics and Intercultural Communication, 2, 125 - 128.

Owen, D. (2017). The new media's role in politics. Bbvaopenmind. Available at: https://www.bbvaopenmind.com/en/articles/thenew-media-s-role-in-politics/

Razeto, L. (2008). Un análisis alternativo de la actual crisis económica global y sus vías de superación. Polis, 21. Available at: https://journals.openedition.org/polis/2906

Röckel, M. (2017). Who rules the internet? Dotmagazine. online Available at: https://www.dotmagazine.online/issues/whorules-the-internet/who-rules-the-internet Sánchez, Á. (2018). Los 100 dias de Puigdemont en Bruselas. El país. Available at: https://elpais.com/politica/2018/02/07/actualida d/1517991992_411354.html

Shaw, J. M. (2014). Illusions of Freedom: Thomas Merton and Jacques Ellul on Technology and the Human Condition. Eugene: Wipf and Stock Publishers.

Sheigal, E. I. (2000). Semiotics of Political Discourse: Monograph. Moscow: Institute of Linguistics of the Russian Academy of Sciences. Verificar universidad

Stanley, J. (2016). How Propaganda Works. Princeton: Princeton University Press.

Ukhov, P., Ryapukhin, A., Biriukova, N., Biryukova, A., \& Dmitrochenko, B. (2020). Problems of distance learning in the lms moodle environment through the eyes of students of Moscow Aviation Institute during quarantine (self-isolation). Revista Inclusiones, 7(3), 412-426. 